\title{
Patient satisfaction with home-birth care in The Netherlands
}

\author{
Jan J Kerssens $\mathrm{PhD}$ \\ Senuor Research Fellow at the Netherlands Instıtute of Prnmary Health Care (NIVEL), \\ Department of Consumers Research, PO Box 1568, 3500 BN Utrecht, The Netherlands
}

KERSSENS J J (1994) Journal of Advanced Nursing 20, 344-350

Patient satisfaction with home-birth care in The Netherlands

One of the necessary elements in an obstetric system of home confinements is well-organized postnatal home care In The Netherlands home care assistants assist midwives during home delivery, they care for the new mother as well as the newborn baby, instruct the family on infant health care and carry out household duties The growing demand for postnatal home care is difficult to meet, this has resulted in a short supply of the most popular day care programme and a level of provision which does not result in adequate services This study acknowledges the patient perspective of maternity home care in order to contribute to its organization The majority (79\%) of service centres were willing to participate A total of $1812(81 \%)$ women who recently gave birth to a child responded to a postal questionnaure addressing the quality of care according to five dimensions avallability, contınuity, interpersonal relationships, outcome and assistant's expertise Almost one-third of the new mothers rated the avalability as inadequate while the assistant's expertise was rated positively Postnatal maternity home care is personalized, small-scale, and recognizes childbirth as a life event Furthermore, it is relatively inexpensive and contributes to the satisfaction of recipients

\section{INTRODUCTION}

The quality of health care services is of great and continuing concern to government, financiers, professionals and patients The responsibilities of medical, nursing and allied professionals in this respect are clearly recognized Quality assessments are usually made according to their perspective and held against their standards

Acknowledgement of the patient's perspective in quality assurance in health care (the boundary with research is vague) has only been highlighted in recent years and has given nse to a new area of quality evaluation or patient satisfaction (Hulka et al 1970, Ware et al 1983, Pascoe 1983, Hall \& Dornan 1988, Campen et al 1992)

Compelling reasons have been advanced for involving the patient's perspective (Locker \& Dunt 1978, Larsen et al 1979, Fleming et al 1988, Bond \& Thomas 1992) One of the reasons is that publicly funded health services are often in a seller's market (Vuori 1991) where patients are restricted by financial mandates to select alternative services, based on consideration of cost and quality

In regard to Dutch postnatal maternity home-birth care, the lack of market forces is regarded as an obstacle to a more consumer-oriented service Publicly insured persons (about $60 \%$ of the population) are eligible for financial compensation only if care is provided by a registered maternity home care centre by vurtue of the Health Insurance Act 1966 But the rhetoric and reality may be quite different domains In the Britsh National Health system, for unstance, market forces are more evident, but this situation has not made the services more 'consumerled' This study tries to answer the question of whether or not patients are still satisfied with postnatal maternity home-burth care

Before presentung the reason for and the result of the study, the main features of the Dutch obstetric system will be explained (see also Kloosterman 1984, Hingstman \& Boon 1988 and, for comparison with other countries, 
Scherjon 1986 and Torres \& Reich 1989) Special attention will be pard to the structure and process of maternity home care because there is no equivalent system in the rest of the world

\section{THE DUTCH OBSTETRIC SYSTEM}

The distunctuve features of the Dutch obstetric system are a large number of home burths and a relatively low rate of medical intervention (Treffers et al 1990) Because pregnancy, labour and the postnatal period are considered normal physiological events women are encouraged to give burth at home instead of in hospital The choice between home and hospital delivery is free, but without medical referral patients have to pay for the use of the delivery room Home deliveries are attended by professional midwives or general practitioners (van Teylingen \& McCaffery 1987), preferably assisted by a qualified maternity home care assistant

After home delivery the new mother recovers from childburth at home After hospital delivery women recover from childburth at home as well, because they are discharged from hospital almost immediately (that is, within 24 hours) after normal deliveries Prolonged stay in the maternity ward is only possible following medical referral Approximately $80 \%$ of the new mothers convalesce from labour in their own bedroom at home

One of the necessary elements in the Dutch system is a well-organized structure of maternity home care services which is provided by 76 regional maternity home care centres Qualified maternity home care assistants look after the new mother, as well as the newborn baby and the other members of the family In 1989, approximately 140000 families were helped by almost 5600 maternity assistants After a primary education of 6 years, followed by a secondary education or vocational training for those aged 12 to 15 years, pupil maternity assistants attend a 3-year vocational training course for those aged 16 to 18 years (MDGO-Vz) The curriculum is shared with pupils from other community care services, including general home help, care for elderly and care for physically handicapped A 20-week period of practical trauning in maternity home care is required, but pupils with practical training in one of the other services are welcomed as well

There are two basic programmes of maternity home care, both of them avalable for a penod of up to 8 days after the delivery The service options are aumed at enabling the famuly to cope again when the interventon is at an end The most popular programme is day care (full-tume) in which the assistant spends 8 hours a day with the family to

1 assist the midwife or general practitioner during home delivery,

2 care for the new mother and newborn baby,

3 provide infant health education to the family,
4 perform household services,

5 recognize deviations from normality in mother and baby and, If necessary, contact the midwife or general practitioner

The second basic programme (part-tume) consists of $1 \frac{1}{2}$ hour visits, starting with two visits a day and ending with one daily visit The functions performed are the same as those in day care, but household services are not included On a small scale such postnatal programmes are being carned out in other countries, organized by hospital midwives and (paediatric) nurses (James et al 1987, Arborelius \& Lindell 1989)

The relative frequency of the two programmes is $67 \%$ for day care and $19 \%$ for the visists Because day care is not always avalable at the start of the programme, visits are substituted until day care is provided These combination programmes form $14 \%$ of all programmes Recently, another programme has been added partal day care In this programme, the assistant spends about 5-6 hours a day with the family Again, all functions are performed, but household services only partially

\section{GROWING DEMAND FOR MATERNITY HOME-BIRTH CARE}

The demand for maternity home care has changed during the period 1955-1987 Figure 1 illustrates these changes After 1975 onwards, the demand for maternity home care did rise again because of the short stay in hospital after delivery followed by postnatal care at home (Butter \& Lapre 1986) and a rising number of births Nowadays almost all women who give birth at home want postnatal home care, as do the majonty of women who give birth in hospital

This growning demand is not easily met A reduction in programme duration (from 9 to 8 days) because of a (governmental) spending cut brought some relief in the mid-1980s, but nowadays the centres are short of staff The popularity of the profession is decreasing The pressure to economize impedes an increase of the very low wages The job becomes more demanding because of the growing number of serious family problems (e g divorces), the growing number of difficult cases caused by some women being discharged from hospital too soon, and the added difficulties of having to deal with a larger number of immigrants (Teijlungen 1990) There are not enough pupils for the vocational training course and the centres find it difficult to recruit new assistants The turnover rate ( $\pm 15 \%$ per annum) amongst maternity home care assistants is quite high Irregular working hours are hard to combine with running a household

This has resulted in a situation where day care programmes are not avalable for everyone and the number of programme days are not always up to standard, in spite of 
Figure 1 Development of number of burths in The Netherlands according to location of delivery and postnatal maternity home care in the period 1955-1987

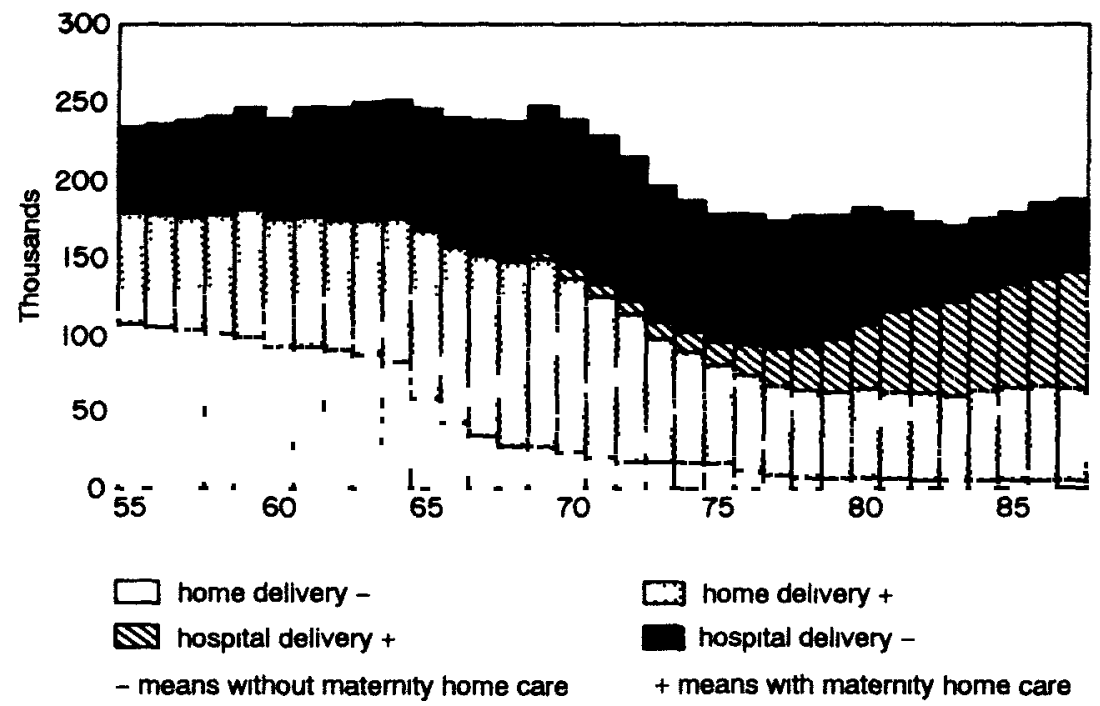

the Dutch government's explicit policy that 'without sufficiently avalable postnatal maternity home care of good quality, a system of home deliveries is inconcervable' (Tweede Kamer 1989)

\section{THE RESEARCH PROJECT}

Our research project dealt with two questions arising from this statement

1 In the patient's view, is maternity home-birth care sufficiently accessible in terms of day care programmes and the number of days care is provided?

2 In the patient's new, is maternity home-birth care of good quality?

In the context of this study patients are women who very recently gave burth Mothers or infants were not included who developed serious complications before the programme had finshed Durng 1 week in September 1990, 1812 (out of 2242) new mothers responded to a postal questonnaire The self-administered questionnaire was partly based on a patient satisfaction study carmed out by the research department of the National Association for Home Care in a maternity home care centre near Amsterdam Aurport (Bastuaenen \& Dresmé 1989) It was adapted slightly for ease of data entry

Staff in the majority of the Dutch maternity home care centres (60 out of 76) were willing to participate in the study and the combined response of women and staff of centres resulted in a total response of $64 \%$ Two of the centres did not participate because of demand problems, probably leading to a slight overestimation of accessibility of matermity home care services in the results Concerning the second question the response is likely to provide representative results to represent average Dutch conditions

\section{Quality of care}

Quality of care is explored according to various aspects accessibility, contmuity of care, technical quality (expert1se), interpersonal relations and efficacy or outcome charactenstics (Roberts \& Tugwell 1987) In case of obstetric care contunuity emerges as an important issue (Zweig et al 1986), as well as information about health education of clients (Jacoby 1988)

Emphasis on access to service in this study justufies a separate research question Access relates to programme characteristics and number of service days included The quality in the second research question is assessed in relation to four of the five previous mentioned functions of maternity home care These functions concern the assistant's expertise The fifth function (need for contact with the midwife or general practitioner) has not been investigated because lay evaluation of this function seems to be problematic The four functions were itemized in 18 Likert-type statements rated in the categories goodsatısfactory-neutral-unsatısfactory-bad

There are some problems, however, with using patient's evaluation ratungs of health care One of these is the lack of meanungful comparative figures This makes levels of satısfaction in absolute terms and in isolation from other data meaningless As high levels of satısfaction (Zastowny et al 1983) can be expected, one cannot accept the ratungs at face value

\section{Comparative base}

In order to interpret results a comparative base is formed Imagine a situation where everything proceeds according to expectations of the mother and her family This condition is fulfilled in the group of women who 
Table 1 Factual reports concerning four dimensions of quality of care $(n=1812)$

\begin{tabular}{|c|c|}
\hline Dimension/aspect & $\begin{array}{l}\text { Percentage } \\
\text { positive }\end{array}$ \\
\hline \multicolumn{2}{|l|}{ Accessibility } \\
\hline Received preferred kınd of programme & 82 \\
\hline Length of programme 8 days & 56 \\
\hline Assistant present during home delivery ${ }^{1}$ & 57 \\
\hline \multicolumn{2}{|l|}{ Continuity } \\
\hline One assistant during entıre programme & 73 \\
\hline \multicolumn{2}{|l|}{ Interpersonal relations } \\
\hline Recommend assistant to others & 80 \\
\hline \multicolumn{2}{|l|}{ Outcome } \\
\hline $\begin{array}{l}\text { Famulies able to take care of themselves at } \\
\text { end of programme }\end{array}$ & 83 \\
\hline $\begin{array}{l}\text { Group of mothers to which all above } \\
\text { dimensions/aspects applies (comparative } \\
\text { base) }\end{array}$ & 8 \\
\hline
\end{tabular}

'This aspect of accessibility related only to women who gave burth at home $(n=751)$

- wanted to give birth at home and did so,

- received the kind of care they preferred,

- were given this care for at least 8 days,

- were delivered at home, attended by a midwife or general practitioner while an assistant was present,

- had the same maternity assistant throughout the entire programme,

- got along well with this assistant, and

- were able to take care of their familes at the end of the programme

This group of women, for whom all the conditions are normal, comprises only $8 \%$ of respondent mothers Table 1 summarizes the percentage of new mothers' factual reports about the care recelved

\section{RESULTS}

\section{Accessibility}

The majority of families (83\%) prefer the day care programme over visits $(14 \%)$ Combination programmes (2\%) and partial day care (2\%) are not very popular (see Table 2) To a large extent the programme preferences are met, although approximately a quarter $(24 \%)$ of the families in favour of day care have visits on the first days, followed by day care on the remaining days

About $40 \%$ of the familes had not taken this situation into account The main reason for supplynng the combination instead of the day care programme is shortage of staff

Even more serious is the situation concerning pro-
Table 2 Relative number of preferred and actual received programmes $(n=1803)^{*}$

Actual received programme

\begin{tabular}{lllll}
\hline $\begin{array}{l}\text { Day } \\
\text { care }\end{array} \quad$ Visits & $\begin{array}{l}\text { Combi- } \\
\text { nation }\end{array}$ & $\begin{array}{l}\text { Partial } \\
\text { day care }\end{array}$ & $\begin{array}{l}\text { Row } \\
\text { total }\end{array}$ \\
\hline
\end{tabular}

Preferred programme

\begin{tabular}{lrrrrr} 
Day care & $\mathbf{7 6 \%}$ & $2 \%$ & $21 \%$ & $1 \%$ & 1495 \\
Visits & $1 \%$ & $\mathbf{9 6} \%$ & $3 \%$ & $0 \%$ & 244 \\
Combination & $11 \%$ & $17 \%$ & $66 \%$ & $6 \%$ & 35 \\
Partial day care & - & $7 \%$ & $28 \%$ & $65 \%$ & 29 \\
Column total & 1151 & 267 & 356 & 29 & \\
\hline
\end{tabular}

$\chi^{2}=2312, d f=9, P<005$

* Nine missing values

gramme length On average, the programmes lasted for 72 days (with a standard deviation of 14 days), while the women opted for 81 days (SD 09 ) Almost half of the families $(44 \%)$ recelved care for fewer days than they would have liked, the difference being almost 2 days Programme days are most frequently lost in the postnatal change from hospital to home Owing to an irregularity both the hospital and the maternity home care centre charge for this day, much to the surprise of the women And again, shortage of staff was responsible for receivnng fewer care days The majority of these women $(68 \%)$ could sympathıze with the centres to some extent, and recognuzed the lack of care as being a result of staff shortage Others (32\%) were less understanding and wrote that the centre should organize better

Midwives or general practitioners who attend home confinements are supposed to be assisted by a maternity home care assistant In almost half of the cases ( $43 \%$ ) the baby had been born before the assistant arrived, the reason being the speed of the delivery Midwives or general practitioners should initiate contact with the maternity home care centre earlier than they do

Ninety per cent of mothers in the comparative group ( $n=138$ ) considered the programme of sufficient length, compared with $69 \%$ of the other group A difference of $21 \%$ was noted

\section{Technical expertise (nursing assistants)}

Figure 2 shows the evaluative ratung of the quality of care, related to maternity assistant's expertise in carrying out four different functions Figure 2a shows the relative number of mothers who rated the quality as 'good' using the items concerning the assistance during home delivery The newborn baby was taken care of and the bedroom was properly cleaned according to the vast majonty $( \pm 85 \%)$ of the women The co-operation between midwife and 
Flgure 2a Assistance during home dellvery

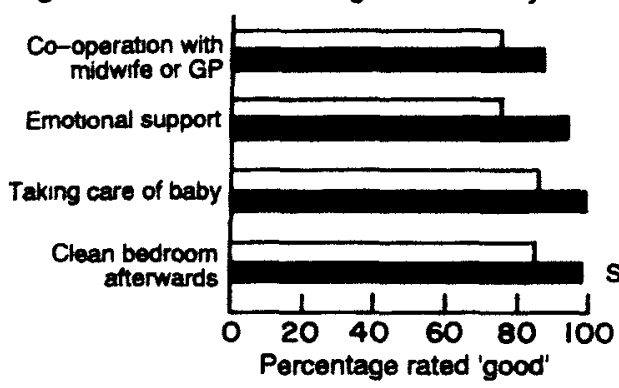

Figure 2c Provide health education

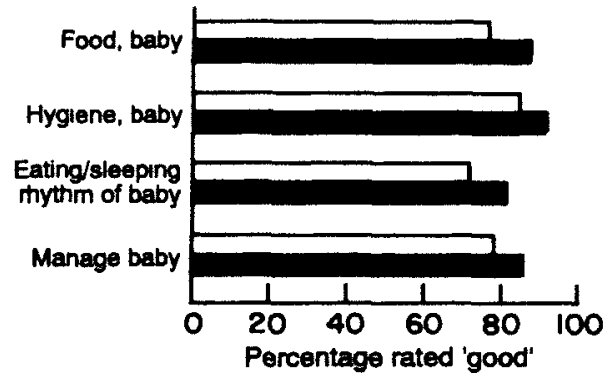

Mothers' ratung
Figure 2b Care for mother and newbom baby

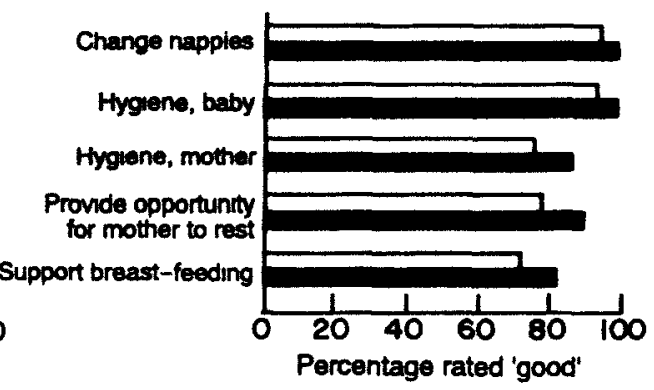

Figure 2d Household services

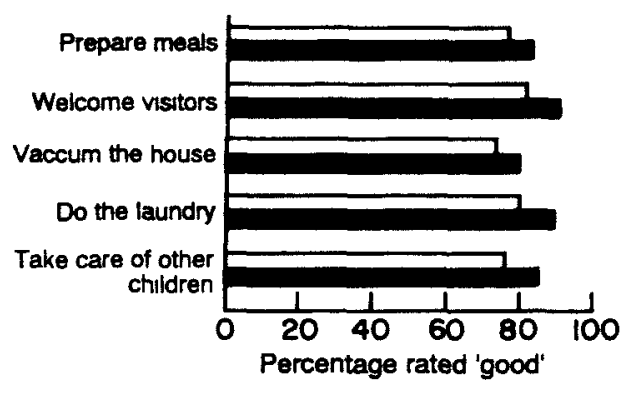

Comparative base

Figure 2 Evaluation of assistant's expertise Relative number of women who rated 18 items concernung four functions as 'good'

assistant was, on average, rated slightly less positively, the same apphes to receiving emotional support $( \pm 75 \%$ rated this item as good) Mothers in the comparative group ranked the assistant's expertise even more highly, especially related to receiving emotional support

Figure 2b shows the percentages of new mothers who rated assistance with personal hygiene highly Care for babies' personal hygiene and changing their nappies are rated very highly ( $\pm 94 \%$ of the mother rated 'good') Care for mothers' personal hygiene, providing enough rest for them and advising about the process of breastfeeding the baby are rated as good by $\pm 75 \%$ of the women The comparative base ratings are also shown Care for the babies is rated very highly, even more so than the care for new mothers themselves The differences between the comparative base ratungs and the others (ranges from 4 to $10 \%$ ) are also less pronounced than those calculated using the previous ratıngs Overall, the mothers are quite satisfied

Figure 2c shows sumular results with respect to the evaluation of health education, feeding the baby, attending to personal hygiene, eatıng and sleeping and general care of the baby The new mothers were satusfied, but less explicitly so than about personal hygiene Again, the difference between the comparative base and the remainder are consistent but small

Evaluation of the assistant's expertise in the last function, domestic activities, is rated similarly to those in the others (see Figure 2d) Again $\pm 75 \%$ of the mothers rated the quality in preparation of meals, the welcoming of visitors, vacuum cleaning, doing the laundry and taking care of the other children as satisfactory

\section{CONCLUSION}

The results of this study justify a negative answer to the first research question and a positive one to the second

1 Maternity home-burth care is not sufficiently accessible Day care is in short supply and the average programme duration falls 1 day short of its agreed standard

2 Maternity home-birth care is of good quality All four investigated functions of the assistant's expertise (assistance of midwife or general practitioner during home delivery, care for mother and baby, provision of infant health education to the family, and performance of household services) were rated as very satısfactory

The comparative base showed that in normal conditions that is, when things are as they should be according to expectations by all involved - approxumately $90 \%$ of the mothers regard the programmes as lasting-long enough In less favourable circumstances (which currently applies to the vast majonty of women), $69 \%$ expressed the same view

The reason why the avalability figure shows a larger discrepancy compared with the comparatuve base than the technical quality ratungs is probably a matter of 
disconfirmation of expectations Satusfaction with care relates to the level of expectations (Linder-Pelz 1982a,b) Thus was also demonstrated in the field of obstetrics, 20 years ago by Noyes et al (1974) and recently by Green et al (1990) The expectations of accessibility are explicit disconfirmation is easily noticed in relation to day care programmes of 8 days The expectations of the assistant's expertıse are probably more ambiguous whle it is also likely that disconfirmation is experienced less often

The results did not reveal association between technical quality, continuity, interpersonal relations and outcome on the one side and avaulability on the other side A multuvanate regression analysis of the same data is reported elsewhere (Kerssens 1993) This analysis showed that apart from the actual programme length the outcome measure was strongly associated with the evaluation of programme length Satusfaction figures dropped sharply from $90 \%$ with positive outcome to $50 \%$ if the outcome was less positive That is, when the mother was not able to take complete care of her famly at the end of the programme, the chance of being satisfied is half

\section{Decreased access}

The pressure to reduce health care expenses has led to decreased access to the service But erosion of maternity home care can eventually undermme the Dutch system of home confinements, resulting in a less agreeable and more expensıve postnatal maternity care Butter \& Lapré (1986) calculated the price of maternity home care compared with hospital-based maternity care, the latter being twice as expensive as the former Postnatal maternity care is the most substantial cost component of total obstetric care

Consideration of costs is not the main issue for the new mother and her family The Netherlands has a partly public (covering $60 \%$ ) and partly private health insurance system (covernng $40 \%$ of the population) Publicly insured women are obliged to pay $12 \%$ of the costs themselves Privately insured women are payed a fixed amount of money urrespectuve of whether or not they spend it on postnatal care This sum will buy them a 6-day care package Many mothers prefer 8 days and are prepared to pay about $25 \%$ of the costs out of their own pocket Kleiverda et al (1990) showed that financial considerations are also of little importance in the choice of burth location

\section{Home delivery}

Reasons for preferring home delivery have to do with intmacy and control over the environment, while reasons for preferring hospital delivery relate to feeling safe The same picture emerges from the preferences of care package Although supplementary payment for day care is three tumes as much as that for visits, this does not seem to influence the choice between options Women who choose the visits seem to value privacy more highly and are more eager to get back to normal hfe again after the delivery Furthermore, women who opt for the visits are always helped, for instance, by their mother or other relatives and friends

Taylor (1986) mentions ongoing debate in the Britush National Health Service concerning the choice of maternity services Having conducted a study on consumer's preferences she concludes, 'Important characteristics of the preferred services are accessibility, contunuty, personalized and small scale care and recognition of childbirth as a life event' (Taylor 1986)

This paper has outlined a form of postnatal maternity care which has all these features Moreover, it is relatively inexpensive, fits the World Health Organization's philosophy of primary care and contributes to the satisfaction of recipients

\section{Acknowledgements}

The author is grateful for the financial support of the Dutch Ministry of Welfare, Publıc Health and Culture

\section{References}

Arborelıus E \& Lindell D (1989) Psychological aspects of early and late discharge after hospital delivery an unterview study of 44 famlies Scandinavian Journal of Social Medicine 17, 103-107

Bastıaenen J \& Dresmé J (1989) Evaluation of Maternity Home Care (Hoe de kraamzorg bevalt I Natronale Krusvereniging, Bunnk, The Netherlands (in Dutch)

Bond S \& Thomas L H (1992) Measuring patients' satısfaction with nursing care Journal of Advanced Nursing 17, 52-63

Butter I \& Lapré R (1986) Obstetric care in the Netherlands manpower substutution and differential costs International Journal of Health Planning and Management 1, 89-110

Campen C, van, Fnele R D, Kerssens J J (1992) Methods for Assessing Patient Satisfaction With Primary Care Netherlands Institute of Prumary Health Care, Utrecht

Fleming A S , Ruble D N , Anderson V \& Flett G L (1988) Place of childbirth influences feelings of satisfaction and control in first-tıme mothers Joumal of Psychosomatic Obstetncs and Gynaecology 8, 1-17

Green J M , Coupland V A \& Kitzinger J V (1990) Expectations, experiences and psychological outcomes of childbirth, a prospective study of 825 women Birth 17, 15-24

Hall J A \& Dornan MC (1988) What patients like about theur medical care and how often they are asked a meta-analysis of the satisfaction literature Social Science and Medicine 27, 935-939

Hingstman L B Boon H (1988) Obstetric care in the Netherlands regional differentiation in home delivery Socıal Science and Medicine 26, 71-78

Hulka B S , Zyzansk S J , Cassel J C \& Thompson S J (1970) Scale for the measurement of attitudes toward physicians and primary medical care Medıcal Care 8, 429-436 
Jacoby A (1988) Mothers' views about information and advice in pregnancy and childburth findings from a national study Midwifery 4, 103-110

James M L , Hudson C N , Gebsk V J , Browne L H , Andrews G R., Cnsp S E et al (1987) An evaluation of planned early postnatal transfer home with nursing support Medical Journal of Australia 147, 434-438

Kerssens JJ (1993) Vorm en duur van thuskraamzorg naar het oordeel van kraamvrouwen (Patient's evaluation of postnatal maternity home care programmes) Tydschrift voor Sociale Gezondheidszorg 71, 91-98 (in Dutch)

Kleiverda G, Steen A M , Andersen I, Treffers P E \& Everaerd W (1990) Place of delivery in the Netherlands maternal motives and background variables related to preferences for home or hospital confinement European Journal of Obstetncs and Gynaecology and Reproductive Biology 36, 1-9

Kloosterman G J (1984) The Dutch expenence of domicillary confinements In Pregnancy Care for the 1980s (Zander L G \& Chamberlaune G eds), The Royal Society of Medicine and the MacMillan Press, London

Larsen D , Attksson C C, Hargreaves WA \& Nguyen T D (1979) Assessment of client/patient satusfaction development of a general scale Evaluation and Programme Planning 2, 197-207

Linder-Pelz S (1982a) Toward a theory of patient satisfaction Social Science and Medicine 16, 577-582

Linder-Pelz S (1982b) Social psychological determinants of patient satisfaction a test of five hypotheses Social Science and Medicıne 16, 583-589

Locker D \& Dunt D (1978) Theoretical and methodological issues in sociological studies of consumer satisfaction with medical care Social Science and Medicine 12, 283-292

Noyes R W , Levy M I , Chase C L \& Udry J R (1974) Expectation fulfilment as a measure of patient satisfaction Amencan Journal of Obstetrics 118, 809-814

Pascoe G C (1983) Patient satisfaction in pmmary health care a
Lterature review and analysis Evaluation and Programme Planning 6, 185-210

Roberts J G \& Tugwell P (1987) Comparison of questionnaires determining patient satisfaction with medical care Journal of Health Services Research 22, 637-654

Scherjon S (1986) A companson between the organization of obstetncs in Denmark and the Netherlands British Journal of Obstetncs and Gynaecology 93, 684-689

Taylor A (1986) Matemity services the consumer's new Journal of the Royal College of General Practıtioners 36, 157-160

Teljlingen E R , van \& McCaffery P (1987) The profession of midwifery in the Netherlands Midwfery 3, 178-186

Teljlungen E R , van (1990) The role of maternity home care assistant and its significance for the Dutch midwifery profession International Journal of of Nursing Studies 27, 355-366

Torres A \& Reich M R. (1989) The shift from home to institutional childbirth a comparative study of the United Kingdom and The Netherlands International Journal of Health Services 19, 405-414

Treffers P E , Eskes M , Kleiverda G \& Van Alten D (1990) Letter from Amsterdam home births and minimal interventions Journal of the American Medical Association 264, 2203-2208

Tweede Kamer 1988-1989, 20800, XVI, nr 163 (1989) Government Policy and Kloosterman's Advce (Regenngsstandpunt Adviescommissie Kloosterman) SDU, 's-Gravenhage (in Dutch)

Vuori H (1991) Patient satisfaction does it matter? Quality Assurance in Health Care 3, 183-189

Ware JE, Jr, Snyder MK, Wright WR \& Davies AR (1983) Defining and measuring patient satısfaction with medical care Evaluation Programme and Planning 6, 1-15

Zastowny T R, Roghmann KJ \& Hengst A (1983) Satısfaction with medical care replications and theoretic reevaluation Medical Care 21, 294-322

Zweig S , Kruse J \& LeFevre M (1986) Patient satisfaction with obstetnc care Journal of Family Practıce 23, 131-136 
This document is a scanned copy of a printed document. No warranty is given about the accuracy of the copy. Users should refer to the original published version of the material. 